\title{
Maintaining Ethnicity and Social Networks: Engkor Lorgow, Lion, Dragon Dance, Performing Arts of the Chinese Ethnic Group in Udonthani Province
}

\author{
Chiraphan Ieamkaew
}

Fine and Applied Arts Research Program,

Faculty of Fine and Applied Arts,

Mahasarakham University, Thailand

\section{Supachai Singyabuth}

Faculty of Fine and Applied Arts, Mahasarakham University, Thailand

\section{Ourarom Chantamala}

Faculty of Fine and Applied Arts, Mahasarakham University, Thailand

DOI: https://doi.org/10.36941/ajis-2020-0112

\section{Abstract}

The research titled "Maintaining Ethnicity and Social Networks: Engkor Lorgow, Lion, Dragon Dance Performing Arts of the Chinese Ethnic Group in Udonthani Province" was qualitative research that emphasized on investigated and collected data from the field study, document, and related research and presented in descriptive analysis, particularly at Thung Si Muang Annual Festival in 2018. The objectives of the study consisted of three criteria: 1) to study of the development of the Chinese ethnic group in Udonthani, 2) to analyze the role of the Engkor Lorgow, Lion, Dragon Dance Performing Arts in maintaining ethnicity and social network of Chinese ethnic group in Udonthani, and 3) to analyze how the culture of Engkor Lorgow, Lion, Dragon Dance Performing Arts helped created social group between Chinese ethnic group and the local people in Udonthani. The study results found that the Engkor Lorgow, Lion, Dragon Dance was part of the ritual at Chao Pu-Ya shrine. The Chinese ethnic group worked together on the ceremony by holding the Chinese Opera to show the belief and faith of traditional Chinese culture and to gather all Chinese together to maintain their ethnicity and create social networks with one another. Chinese Operas were held annually in Thung Si Muang, Udonthani province, Thailand, and had adapted the Engkor Lorgow, Lion, Dragon Dance to be more spectacular and fit in with social contexts in Udonthani. The dance was promoted to be one of the provincial identities and played an important role in tourism in Udonthani. Thus, the Engkor Lorgow, Lion, Dragon Dance has been a ritual that helped assemble and created social networks between the Chinese ethnic group and other ethnic groups in Udonthani province.

Keywords: Chinese ethnic group, Engkor Lorgow, Lion, Dragon Dance, Performing Arts, ethnicity, social networks

\section{Introduction}

Chinese and Thai have a long relationship since the Sukhothai era. The research on The Chinese and Production of Public Culture in Khon Kaen Municipality by Chantranuson (2008) talked about the 
relationship between the Chinese and Thai people by stating that since the Sukhothai period, the Chinese people started to come into Thailand in a form of trade caravans and established their semipermanent settlement. In the Ayutthaya period, More Chinese people flooded into the country. From the Chronicles of Rattanakosin (King's Private Secretary Division, 1983), King Rama I wanted the Chinese people to move their settlements from the former place, which was around the Royal Palace, to the area along Wat Sam Pluem canal to Wat Sampheng canal. It can be seen that during the Rattanakosin period, the Chinese people were settling in Bangkok and moved up to Udonthani province during the time of King Rama V, which was in $2436 \mathrm{BE}$, the year when Udonthani city was established.

When the political riot, economic recession, and natural disaster occurred, the Chinese moved their settlements from Mainland China to find new settlements in Southeast Asia, especially in Thailand, which was an appropriate area to settle in since Thailand was located in an important commercial hub, and in Udonthani, which is located in the northeast of Thailand, which hereafter will be referred to as Udonthani. The Chinese brought in their culture, tradition, and rite when migrated to Thailand to settle and reserve the areas as a community, which later created a Chinese community or a market.

The Chinese established themselves as merchants after they became wealthy through their livelihood and began to establish shrines as the center of souls and to conduct their rituals. The god of $\mathrm{Pu}-\mathrm{Ya}$, a Chinese spirit, was invited to dwell in this shrine, where the Chinese called Chao Pu-Ya spirit shrine, and strictly conducted worship ceremony festival or Chinese Opera following their belief and faith (Triyachart, 2018). The ceremony aims to support their luck and get rid of the bad things through the art performance of Engkor Lorgow, Lion, Dragon Dance. The dance is ceremonial assembles from the basis of ideology, discourse, historical background, literature, belief, and faith of the Chinese ancestor who believed that the performance was a representative of the heaven, the gods, the emperors, the and heroes (Senaputra , 2018).

\section{Review of Literature}

The ceremony of Lion and Dragon Dance has been practiced in Mainland China. It was reconceived again and resulted in the composing art performance of Engkor Lorgow, Lion, Dragon Dance, to reflect more gratitude (Tantisutaphong, 2017). As Soonthornpasuch (2005) had provided the definition of ethnicity, or ethnic relations, that it is the creation of good relationship and the decent of families and culture. The dance helped preserve their Chinese identity and maintain their ethnicity; it also helped create a Chinese network and firmly encouraged good relations between the Chinese.

Besides the effort in maintaining their own ethnicity, the Chinese had also created networks with other ethnic groups in Udonthani through the holding of the Chinese Opera Festival and Thung Si Muang annual festival for Udonthani people (Pischunchom, 2016). The Engkor Lorgow, Lion, Dragon Dance was adapted to correspond with the social contexts of Udonthani to show more gratitude and to present stories of the past as a memoir. The reproduction of the dance, which integrates the imagination of the Chinese in Udonthani. Wipawin (2015) stated that social networks are part of a structure within the society that was built by outsiders. The networks might be from the gathering of people within their own group or between two groups of people that are related through different forms of relationships and the interactions within the society. The Engkor Lorgow, Lion, Dragon Dance, therefore, illustrates a combination of traditional and contemporary styles to form a relationship amongst the Chinese people, as well as between the Chinese people and other ethnic groups in Udonthani. However, the primary purpose is to maintain the Chinese ethnicity amongst the different ethnic groups in Udonthani. Therefore, the performance of Engkor Lorgow, Lion, Dragon Dance is always meaningful.

The phenomena indicated that the study of the role of Engkor Lorgow, Lion, Dragon Dance Performing Arts in maintaining ethnicity and creating social network toward human and society was linked to the theoretical framework in Humanities and Social Sciences and the theory of Performance Art. 


\section{Research Methodology}

This research was qualitative research that collected data from a filed study from Chao Pu-Ya shrine in Udonthani and the collected data on the development of the Chinese groups in Udonthani, as well as Engkor Lorgow, Lion, Dragon Dance performing art. The data used interview methods to elicit the data from the present generation of Chinese, along with the documents and related research, in order to investigate the maintaining of ethnicity and social network creation of Chinese people in Udonthani. The researcher employed the ethnicity theoretical framework from the four following key-scholars in Thailand: 1) Suthep Soonthornpasuch, 2) Srisak Wanliphodom, 3) Chavivun Prachuabmoh, and 4) Prasit Leepreecha. This research also employed the theoretical framework in Social networking from two following key-scholars in Thailand: 1) Namtip Wipawin and 2) Thanapauge Chamaratana, to identify the Chinese ethnicity and social networking through Engkor Lorgow, Lion, Dragon Dance Performing arts with descriptive analysis presentation.

\section{Research Tools}

The researcher collected data from three main tools as follows:

1. Interviews as the primary tool for collecting data with open-ended questions and forming an understanding of the interview questions without using scripts

2. Field study note to record the fieldwork with the following structure: research objective, research proposal, and research plan (activities/time) to determine the primary and secondary objectives.

3. Recording devices such as cameras for taking pictures and voice recorders for recording audiovisual data.

\section{Data Collection}

Based on the research objectives, the researcher had defined the scope of the research timeline and the areas of study using Thung Si Muang annual festival in 2018. The timeline for the research was one year, starting from January to December 2018. The data collection relied on the research objectives. The researcher divided the data into three following parts:

1. Data from documents and audio-visual information related to the topic of Chinese historical development in Udonthani, Chao Pu-Ya shrine history in Udonthani, and Engkor Lorgow, Lion, Dragon Dance art performance, which linked to the provincial development policy of Udonthani province.

2. Data from the interviews, the researcher focused on the people closely related with field study phenomena, which were categorized into two groups; focus group and individual interview.

3. Data from the observation, the researcher applied integrated methods of participated and non-participated observation to analyze conditions in each situation.

\section{Research Objectives}

1. To study the development of Chinese in Udonthani province

2. To analyze Engkor Lorgow, Lion, Dragon Dance art performance in maintaining ethnicity and social network creation

3. To analyze the Engkor Lorgow, Lion, Dragon Dance art performance in social network creation between Chinese with other ethnic and culture and society in Udonthani

\section{Data Analysis}

The researcher analyzed the data based on the research objectives, which can be divided into document 
analysis and field study analysis as follows.

1. Document data analysis is aimed to study and analyze the data from relevant documents and research by studying concepts and theories to find out the study results.

2. Field study data analysis is aimed to study and analyze of data from research tools and data collecting by using two types of analysis as follows:

a. Inductive data analysis to interpret data from solid data or field study

b. Data classification analysis by using theory as the main data categorization

\section{Research Discussion}

The art performance of Engkor Lorgow, Lion, Dragon Dance is a medium that was used to build the relationship to maintain the ethnicity and social network creation of the Chinese people in Udonthani. Therefore, the researcher applied the Ethnicity concept and Social Network creation for the research discussion.

\subsection{The development of Chinese people in Udonthani province}

The evolution of the Chinese people in Udonthani province had been related to the physical area and the development of Udonthani becoming a city. The location of the city had meaning in both the political aspect and the settlements of the people. The Chinese people had been having social evolution since they followed the army of Prince Prachaksinlapakhom. Some followed the army to trade, and some volunteered in the army. They eventually permanently settled in the city, followed by the migration of other Chinese people until a Chinese community was established alongside the establishment of the city itself. The Chinese people were able to establish their community, which was called the "Old Market," and later expanded to the new area and called the "New Market" to continue their careers as traders according to their skills and expertise. The Chinese people were able to strengthen their community, starting from the ritual level to the establishment of their own Chinese school, Chao $\mathrm{Pu}$-Ya Shrine, the Chao Pu Ya Foundation in Udonthani province, and the Chinese Merchant Association of Udonthani (Chinese Cultural Museum, 2016). These efforts were put in place as a way to maintain their ethnicity and create a social network amongst the Chinese people themselves and between the Chinese people and other ethnic groups in the province. As for the role of the Chinese people in helping establish the city, They helped build the first City Pillar Shrine of Udonthani, as well as participating in the ceremony to bring in the statue of Thao Wessuwan and Phra Phuttha Phothong to be placed in the front and on the side of the shrine. A Chao Pu Ya shrine was built in Thung Si Muang area as a place to hold ceremonies and to restore the memories of the Chinese people. Additionally, the Chinese Arche was also built to commemorate King Rama IX, as well as the construction of the hall for the King within Thung Si Muang area. Eventually, when the Chinese people became wealthier, they established nine more Chinese organizations and eleven associations of different Chinese families that still exist today.

\subsection{Engkor Lorgow, Lion, Dragon Dance art performance of Chinese in Udonthani province}

The researcher viewed the Engkor Lorgow, Lion, Dragon Dance art performance as a medium for building relationships in order to understand the maintaining of ethnic and social network creation of Chinese Udonthani Province. From the explanation by Pantoomkomol (1995), every time communications emerged through a medium such as an art performance, the relationship between performers would always be expressed. Therefore, the expression between the actors must constantly be moving to adapt to the surroundings or communication. When analyzing from explanations, it was found that the phenomenon of Chinese performing arts, Engkor Lorgow, Lion, Dragon Dance is the medium to help maintain the ethnicity and communication or creation of social networks amongst the Chinese people and between the Chinese people and other ethnic groups. The performance also acts 
as a bargaining factor in becoming part of the Udonthani people. Therefore, the Chinese constructed Engkor Lorgow, Lion, Dragon Dance art performance, was used as a medium and communication strategies.

When Engkor Lorgow, Lion, Dragon Dance art performance became part of the Thung Si Mueang annual festival and an important role in tourism, the identity of Udonthani people, and gained recognition from Udonthani people, the Engkor Lorgow, Lion, Dragon Dance art performance had adapted itself to the social context of Udonthani province. The art performance has continuously being developed or produced meanings to correspond with society or to adjust the method of communication and expression of the ritual. Therefore, Engkor Lorgow, Lion, Dragon Dance art performance is a phenomenon term of social context in Udonthani province. This ritual and performance bring mutual benefits between the Chinese people and other ethnic groups in Udonthani province, as well as maintaining ethnicity and creating social networks for Chinese people and in aspects of performing arts of Udonthani province. Both the ritual and art performance can not be separated from each other, apart from being explained from different perspectives. This led to a new discovery in the aspects of the art performance of Engkor Lorgow, Lion, Dragon Dance from the concept of maintaining ethnicity, and the social network creation as another dimension of the Chinese people's action to strongly maintain their ethnicity, along with social networks creation.

\subsection{Engkor Lorgow, Lion, Dragon Dance art performance in aspect of maintaining ethnicity and social network creation between Chinese and Chinese and Chinese with other groups}

In the research of maintaining ethnicity and social networks creation in Engkor Lorgow, Lion, Dragon Dance performance art of Chinese at Udonthani province, the researcher used the concept of maintaining ethnicity and social network creation to study the ways of Chinese people maintains their ethnicity and social network creation in Udonthani province. The performance also acts as a tie in the effort of building relationships. From the concept of ethnicity, maintaining the ethnicity did not only rely on traditional rituals, but also the integration of the social context of Udonthani province. Therefore, the study indicated that ethnicity needs to adapt to fit in with the social contexts, current trends, and relevant government policies. Resulted in the creation Engkor Lorgow, Lion, Dragon Dance art performance with more spectacular components and led to the recognition by the Chinese people in Udon Thani province as a part of creating the identity for Udonthani as well as the economy and tourism. Thus, the maintaining ethnicity intertwines social networks with Engkor Lorgow, Lion, Dragon Dance art performance as a medium for linking relationships.

The researcher employed ethnicity theoretical framework to demonstrate the phenomena based on four key-scholars in Thailand were as follows: 1) Soonthornpasuch (2005), 2) Wanliphodom (2001), 3) Prachuabmoh (2004), and 4) Leepreecha (2014), who were all famous in this areas and had similar ideas of ethnicity among other groups. The researcher summarized the concept of maintaining ethnicity as a key point of relationship for creating relationships in Chinese or between groups. The relationship creation may occur through kinship or ritual traditions as mediators to reproduce for integration, identification, mutual benefits, and sustainability. The researcher had adopted the knowledge as a guideline in explaining the meaning Engkor Lorgow, Lion, Dragon Dance art performance art, along with the concept of social network creation.

From the explanation of social networks or social network creations from Wipawawin (2015), social networks are a type of network that is linked by relationships. Similarly, Chamarat (200o) explains that the concept of Social Network Concept was developed from the base of the Exchange Theory. The researcher, therefore, summarized the concept of social networks as the association, the connection, and the relationship. Consequently, social networks were created for creating relationships with various purposes, sharing mutual benefits, informing and declaring identity, and determining location. 


\section{Engkor Lorgow, Lion, Dragon Dance Art Performance art with Maintaining Ethnicity of Chinese in Udonthani Province}

The establishment of Udonthani province was related to the migration into the area of the Chinese people. When Prince Prachaksinlapakhom decided to establish Udonthani city, the Chinese people started their settlement by choosing a specific area together as a group and started to build up their relationship. Similar to what Leepreecha (2014) explained that ethnicity is the act of giving importance to the relationship and its context between each group of people within the society, which can help reveal the process between each group of people that creates the social phenomenon. This phenomenon helped created the Chinese community and the market, which is called the old community market, where the Chinese established themselves as merchants. During the time when the Chinese people were building up their identity, they used the trading system as a medium to build the relationship with amongst their Chinese groups as well as between the Chinese groups and other ethnic groups. Due to their skills in trading and negotiation, the Chinese people were able to serve in the Siam government. However, most Chinese people still prefer to establish themselves as merchants according to their skills. This had led to the expansion of another market called the new community market. They helped build the Udonthani City Shrine, both the first and second building, which the structure that maintains the identity of the Chinese in Thung Sri Muang field, which is the center of the city. This phenomenon shows that since the past, the Chinese people tried to build their identity and the relationship within their own Chinese group to maintain their ethnicity. They had also created the network between the Chinese group and groups from different societies and cultures in Udonthani in order to unite the Chinese people of Udonthani.

When Chinese people became wealthy, they established a Chinese organization for maintaining their ethnicity and creating a network amongst the Chinese people, including building a shrine as central areas of worship for Chinese people. The gods of Pu-Ya were invited to be at this shrine: called the Chao Pu-Ya shrine. The Chinese people use the areas for forming their identity through performing rituals since the ritual can bring together different groups of Chinese people. According to Prachuabmoh (2004), the members used culture as a mechanism to create relationships and coordination. They perform the worship to the Gods and organize a Chinese Opera festival, strictly following the tradition and belief which have been carried on since the past.

Soonthornpasuch (2005) explains that ethnic relationship was about building relationships, maintaining ethnicity and culture. The Engkor Lorgow, Lion, Dragon Dance art performance is, therefore, a ritual that helps maintain the ethnicity of Chinese in Udonthani by having Chao Pu-Ya as reserved space to support the ritual. The ritual consists of the gods' invitation parade, sending gods parade, and city tour parade. All three parades were equipped with the traditions, rituals, beliefs, and livelihood of the Chinese. Thus, the parades were like an overview of Chinese livelihood. Therefore, Engkor Lorgow, Lion, Dragon Dance art performance was one of the Chinese ceremonies for maintaining the ethnicity in Udonthani Province by having Chao Pu-Ya shrine as reserved areas.

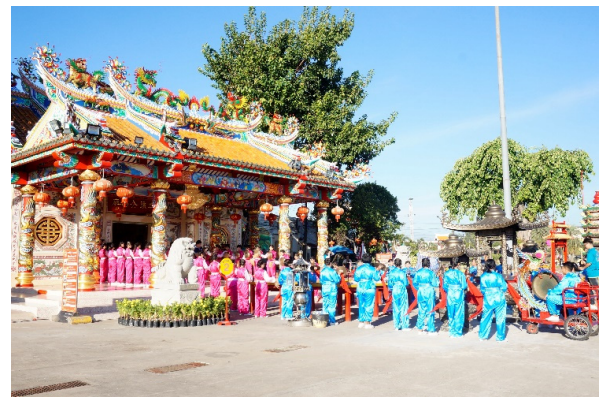

Figure 1: Chao Pu-Ya shrine in Udonthani province: center and tabernacle areas of Chinese Source: Chiraphan Ieamkaew 
The Chinese people revive and reproduce historical stories of the past as a means to inform their identity through the performance art Engkor Lorgow, Lion, Dragon Dance, which has been exhibited in Mainland China and brought back to Udonthani province of Thailand. The performance was presented in the form of rituals or reproduction from China, but more spectacular. Therefore, it was different from the original performance in order to inform the identity of the Chinese people to other ethnic groups that the Chinese are living well in the new social contexts in Udonthani province.

According to Wanliphodom (2001), ethnicity consciousness is a dynamic relationship and always moves and changes all the time. Therefore, Engkor Lorgow, Lion, Dragon Dance has always been performed through intensive production on the basis of reproduction or constantly communicate meanings.

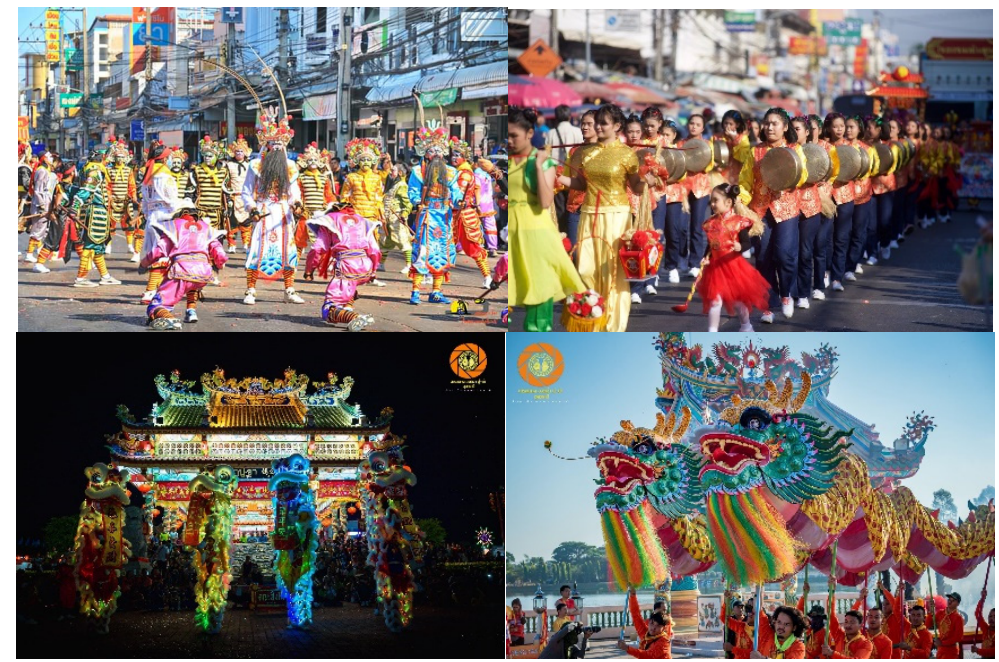

Figure 2: Engkor Lorgow, Lion, Dragon Dance art performance

Source: https://www.facebook.com/puyaudon/infomationchaopu-ya/udonthani

The maintaining ethnicity of Chinese has proceeded with the integrated meaning of Engkor Lorgow, Lion, Dragon Dance art performance through the combination of traditional and modern style. It also helped form groups to create relationships and social networks amongst the Chinese to maintain the stability of the Chinese ethnicity in Udonthani province among the local culture. The art performance of Engkor Lorgow, Lion, Dragon Dance was a mediator in building firm relationships of the Chinese people. Besides, the Chao $\mathrm{Pu}$-Ya spirit shrine was reserved for physical areas to form the Chinese identity and build the relationship of the Chinese society in different levels within Udon Thani province, which is part of maintaining ethnicity.

\section{Engkor Lorgow, Lion, Dragon Dance Art Performance with Social Network Creation of Chinese in Udonthani Province}

When the Chinese people jointly put together the Chinese Opera Festival for the Thung Si Mueang annual festival together with the people of Udonthani, they presented Engkor Lorgow, Lion, Dragon Dance art performance as a medium for social networks creation amongst the Chinese and other ethnic groups. The performance is the representation of identity the Chinese people participating in Thung Si Mueang festival. The opening ceremony of Thung Si Mueang festival at the center stage, which is an area of identity and tourism of Udonthani. Therefore, the ritual of Engkor Lorgow, Lion, Dragon Dance 
was performed more spectacularly. It also brought the story of the past, integrated with the imaginative meaning of the Chinese people in Udonthani. The implications of the performance were to show the identity of the Chinese people, as well as to build a network between them and the people of Udonthani, which resulted in this social phenomenon.

The Engkor Lorgow, Lion, Dragon Dance promoted to be one of the identities of Udonthani province and plays an important role in tourism. The Chinese people are considered as Udonthani people. They were able to obtain an opportunity to build the spirit house of Chao $\mathrm{Pu}$-Ya shrine and the arches gate as a place of worship at Thung Si Mueang, which is the center of the city. When performing rituals, the Chinese people also create a network between the Chinese people and the state, the private, and other sectors, or people Udonthani province by being invited to participate in the performance. Wipawin (2015) defines the meaning of social networks as social systems that are linked by relationships, which caused the Nodes, Individual or Actor, Ties, and Relations. Chamarat (200o) explained the basics of the Exchange Theory that the theory itself consists of a person that is connected through a relationship. The connection from each Node forms a relationship as an outcome. Therefore, the Chao $\mathrm{Pu}$-Ya shrine has been like a stage of expressing their identity and build a relationship amongst the Chinese people and other ethnic groups in Udonthani province.

In addition, The Chinese people created social networks amongst the Chinese and other groups of Udonthani people or creating Thai identity for themselves by performing the Engkor Lorgow, Lion, Dragon Dance at the City Shrine of Udonthani and the Krom Luang Prachaksinlapakhom Monument, the younger brother of King Rama V of the Chakri Dynasty of Thailand, who was the founder of Udonthani, as a way of paying homage to Udonthani as their homeland. The performance is also related to the monarchy as part of a national activity for the Chinese people to express their loyalty toward the monarchy. The faith, the people's belief, and the society and culture of Udonthani province was one reason that made the Chinese people Thai. This includes the art performance of Engkor Lorgow, Lion, Dragon Dance to payback the society around the city center areas, which are central economic and community resources. These phenomena show that the Chinese has created social networks amongst the Chinese people and other ethnic groups in Udonthani by bringing the Chinese identity to connect in both the public and private sectors.



Figure 3: Engkor Lorgow, Lion, Dragon Dance art performance at Krom Luang Prachaksinlapakhom Monument

Source: https://www.facebook.com/puyaudon/infomationchaopu-ya/udonthani 


\section{Conclusion}

According to the study, the researcher found that the Engkor Lorgow, Lion, Dragon Dance art performance is not only a performance of rituals to bring people together, but also act as a mediator for building relationships to maintain their ethnicity and social network creation. Although it was created as an implication of ritual, it was shown and became an art performance in the annual event at Thung Si Mueang festival in Udonthani province, and was recognized to be one of the identities of Udonthani province. Therefore, the ritual and performance bright mutual benefits both the Chinese people and other groups in Udonthani, as well as maintaining the ethnicity and the creation of social networks. Therefore, this was a new discovery of the Engkor Lorgow, Lion, Dragon Dance art performance.

\section{References}

Chamarat, T. (200o). State of Knowledge of Social Network Concept: Articles. 1, 1-13.

Chinese Cultural Museum. (2016). Informational Text. 1.

Leepreecha, P. (2014). Review Article: Paradigms of Studies on Ethnicity. Journal of Mekong Societies, 10(3), 219-242. Pantoomkomol, S. (1995). Art Performance (Modern Drama) ( $1^{\text {st }}$ ed.). Bangkok: Chulalongkorn University Press.

Prachuabmoh, C. (2004). On the Ethnic Study Guidelines. The $2^{\text {nd }}$ Conference of Anthropology Proceeding: Nation, Ethnic, and Diversity in present. Bangkok. Princess Maha Chakri Sirindhorn Anthropology Centre (Public)

Soonthornpasuch, S. (2005). Ethnic Relations. Bangkok: Muang Boran Press.

Wanliphodom, S. 2001. Ethnic Awareness. Bangkok: Academic Conference Paper of Senior Scholar Academic Project, TRF. Princess Maha Chakri Sirindhorn Anthropology Centre (Public)

Wipawin, N. (2015). Networks in a Network Society: Journal of the Thai Library Association, 8(2), 121.

\section{Interviews}

Senaputra, C. (2016,December 18). Personal Interview [Personal Interview].

Tantisutaphong, I. (2017, August 17). Personal Interview [Personal Interview].

Triyachart, P. (2016, December 13). Personal Interview [Personal Interview].

Pischunchom, S. (2016, November 21). Personal Interview [Personal Interview]. 